\title{
SOCIOTECHNICAL TRANSITIONS TOWARDS SUSTAINABILITY IN A MULTILEVEL PERSPECTIVE: OVER VIEW AND FUTURE PERSPECTIVES
}

Gabriela Almeida Marcon Nora ${ }^{1}$ Anete Alberton ${ }^{2}$

\begin{abstract}
The theory of socio-technical transition emerged as a conceptual framework to examine and understand changes towards sustainability. Mapping the relevant intellectual territory to specify a research question is essential to deepen the studies and expand the frontier of knowledge. In this sense, this paper aims to explore the state of the litera ture about socio-technical transitions and MLP, trying to trace an evolution of the existing studies and characterize the multilevel perspective as a framework to further analysis. From there, it will be possible to validate the framework and outline future perspectives on the theme. The review methodology is based on PRISMA recommendations. Due to the relevance to the area and availability of indexed journals, the ISI, Science Direct, Emerald, Willey, and Scopus databases were searched, considering only papers published in peer-reviewed journals. A portfolio of 65 papers was gathered for analysis. It was performed a descriptive analysis of the papers. Afterward, a critical synthesis of the material was underlined. It demonstrates a tendency to combine models and theories to account for the complexity of current socio-technical transition studies. From that, it was possible to draw a few perspectives for future studies about the theme. It concludes that MLP is a valuable framework for addressing socio-technical change and qualitative approaches are still essential to elaborate the theory. Regarding future studies, we suggest that strategy and organizational theories could be brought to the field of socio-technical transitions.
\end{abstract}

Keywords: Socio-technical Transitions; MLP; Multilevel Perspective; Critical Review; Future Perspectives.

\section{TRANSIÇÕES SOCIOTÉCNICAS PARA A SUSTENTABILIDADE À LUZ DA PERSPECTIVA MULTINÍVEL: PANORAMA E PERSPECTIVAS FUTURAS}

\section{RESUMO}

A teoria da transição sociotécnica surgiu como um arcabouço conceitual em busca de examinar e compreender as mudanças em direção à sustentabilidade. Mapear o território intelectual relevante para especificar uma questão de pesquisa é uma etapa essencial para a profundaros estudos e expandir a fronteira do conhecimen to. Nesse sentido, este artigo tem como objetivo explorar o estado da literatura sobre o framework da perspectiva multinível (MLP) a trelado à s transições sociotécnicas, buscando traçar uma evolução dos estudos existentes e caracterizar a MLP. Assim, é possível validar o framework e traçar perspectivas futuras sobre o tema. A revisão da literatura é baseada na recomendação PRISMA. Devido à relevância para a área e disponibilidade de periódicos indexados, as bases de dados ISI, Science Direct, Emerald, Willey e Scopus foram pesquisadas, considerando apenas artigos em inglês, publicados em periódicos revisados por pares. Um portfólio de 65 artigos foi reunido para exame. Foi realiza da uma análise descritiva dos artigos. Fez-se, então, uma síntese crítica do material. Demonstrou-se uma tendência de combinar modelos e teorias para dar conta da complexidade dos estudos atuais sobre transições sociotécnicas. Delinearam-se algumas perspectivas para estudos futuros sobre o tema. Conclui-se que a MLP é uma estrutura válida para abordar a mudança sociotécnica e as abordagens qualitativas são importantes para aprofundar a teoria. Para estudos futuros, sugere-se que teorias de estratégia e teorias organizaciona is sejam ser trazidas para o campo das transições sociotécnicas, buscando robustecer as discussões sobre o tema.

Palavras-chave: Transições Sociotécnicas; MLP; Perspectiva multinível; Revisão crítica; Perspectivas futuras.

RGSA adota a Licença de Atribuição CC BY do Creative Commons (https://creativecommons.org/licenses/by/4.0/).

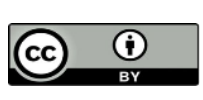

\footnotetext{
${ }^{1}$ Doutoranda em Administração pela Universidade do Vale do Itajaí - UNIVALI, Santa Catarina (Brasil). Email: gabriela@almeidamarcon.com Orcid: $\underline{\text { https://orcid.org/0000-0003-4086-8958 }}$
}

2 Doutorado em Engenharia de Produção pela Universidade Federal de Santa Catarina. Professora titular da Universidade do Vale do Itajaí - UNIVALI, Santa Catarina (Brasil). Email: anete@univali.br Orcid: https://orcid.org/0000-0002-6477-0122 


\section{INTRODUCTION}

Societies are facing persistent socio-environmental challenges. The objectives of sustainable development (SDGs) outlined in the Agenda 2030 elucidate the dimensions of these challenges and their global nature. An unprecedented economic, social, and technological transformation is needed to confront this reality. The socio-technical transition theory emerged as a conceptual framework to examine and understand changes towards sustainability (Geels, 2004; Markard et al., 2012; Lachman, 2013; Forbord \& Hansen, 2020). As social issues became complex, there was a need to expand the exclusively technological perspective to a socio-technical view. There is a growing interest in systems transitions and innovation to promote environmental efficiency (Geels, 2005a; Geels \& Kempt, 2007). The theory assumes that social functions such as urban mobility, electronic communication, water supply, food, energy, and housing are provided by a set of relevant entities. Such entities, namely technologies, companies, supply chains, infrastructure, markets, and regulations, are collectively called the socio-technical system (Geels, 2002; Sorrel, 2015; Gruchmann et al., 2021). Therefore, social functions are fulfilled by these socio-technical systems, consisting of a set of aligned elements, for example, artifacts, knowledge, markets, regulation, infrastructure, maintenance networks, and supply networks (Geels, 2005a). Over the years, with the alignment and co-evolution of the relevant entities and the practices developed, they acquired mutual dependence and became resistant to change (Geels, 2002; Geels, 2004; Geels, 2012).

The primary source of stability in these systems would be the existence of rules, norms, expectations, and shared beliefs that guide the behavior of the different actors within the system called the socio-technical regime. The socio-technical regime, in turn, is characterized by these intangible and underlying structures, for example, engineering beliefs, heuristics, practical rules, routines, standardized ways of doing things, policy paradigms, visions, cultural significance, promises, and social actions (Geels, 2002; Forbord \& Hansen, 2020). Transitions in a sociotechnical system cannot be confused with the substitution of technologies alone. When it comes to transitions, there is not just one line of thought to be followed. There are multiple dimensions, such as geographic or spatial, global structures, justice and power, agency conflicts (Coenen et al., 2012; Truffer \& Coenen, 2012; Binz et al., 2014). Graham \& Thrift (2007), when dealing with maintenance and repair services as a vital source of variation, improvisation, and innovation, emphasize, for example, the importance of the subjectivity, ingenuity, and human work involved in these processes. Several frameworks may be applied to explain socio-technical transitions (Markard et al., 2012).

Mapping the relevant intellectual territory to specify a research question is essential to deepen the studies and expand the frontier of knowledge. In this context, the following research question arises: What is the state of the literature about socio-technical transitions and the multilevel perspective (MLP)? In this sense, this paper aims to explore the state of the literature about sociotechnical transitions and the multilevel perspective (MLP), trying to trace an evolution of the existing studies and characterize the MLP as a framework to further analysis. From there, it will be possible to validate the framework and outline future perspectives on the theme.

\section{THEORETICAL FRAMEWORK: OVERVIEW OF THE MULTILEVEL PERSPECTIVE ON SOCIOTECHNICAL TRANSITIONS}

Alex de Tocqueville first coined the concept of "transition" in the 19th century. Since then, the term has been used by several fields of science and, in the 90s, introduced in socio-technical research (Lachman, 2013). In the words of Geels \& Schot (2007, p. 399/400): "The socio-technical regime is an extended version of the technological regime of Nelson and Winter (1982), which referred to shared cognitive routines in the engineering community and explained the standardized 
development to the along technological trajectories". The evolution of socio-technical transitions and their characteristics is addressed by Köhler et al. (2019). According to Köhler et al. (2019), research on socio-technical transitions can be subdivided into nine themes or directions, which address their different aspects. The referred directions are:

1. Understanding transitions;

2. Politics and power in transitions;

3. Governing transitions;

4. Civil Society, culture, and social movements;

5. Business and industries in sustainability transitions;

6. Transitions in practice and everyday life;

7. Geography of transitions: Spaces, scales, and places;

8. Ethical aspects of transitions: Distribution, justice, poverty;

9. Reflections on methodologies for transitions research.

The primary theoretical references in the field of transition studies for sustainability are the Multilevel Perspective (MLP), the Technological Innovation System (TIS) approach, Niche Strategy Management (SNM), and Transition Management (TM) (Markard et al., 2012). They adopt a systemic perspective to capture the coevolutionary complexity of the main phenomena, such as path dependence and non-linear dynamics. When addressing socio-technical transitions, relevant interdependent and coevolutionary entities combine to form economically significant and geographically extensive systems. That, over time, become increasingly stable and resistant to substantial changes (Rip \& Kemp, 1998; Uhrun, 2000; Geels, 2002). The transition processes cannot be entirely foreseen, and it is admitted that they are only partially planned (Geels \& Schot, 2007; Forbord \& Hansen, 2020). The MLP is a prominent approach on socio-technical transitions characterized as a proposition of how the interaction between various analytical levels can influence the system's development process. It theorizes socio-technical change as a process of niche innovations competing with incumbent regimes (Levidow \& Upham, 2017), departing from an old dichotomy in social sciences between structure and agency (Ismaeel, 2019).

In an explorative and flexible way, this perspective usually portrays a chosen topic, development, or historical action and the elements and interactions connected to it (Geels, 2004; Geels \& Schot 2007; Geels, 2007; Vähäkari et al., 2020). Geels (2004) proposes that change should not be seen only by those who produce it but also by users, as it aims to satisfy social demands. According to the author, the system does not work autonomously. But from the exchange between the actors, the environment, and the artifacts. The MLP expands a unit of analysis of technological products for socio-technical systems that provide social functions such as energy, food, water, urban mobility, housing, and transportation.

As a framework, MLP primarily aims to understand the nature, characteristics, and modes of operation of socio-technical systems; its sources of inertia; the conditions under which it changes; the processes through which transitions to different systems occur; and the conditions under which systems are effectively transformed (Geels, 2004; Geels; Schot, 2007; Markard et al., 2012; Turnheim; Geels, 2013; Sorrell, 2015; Kivimaa; Kern, 2016; Geels et al., 2017). Considering that systems consist of an interdependent and coevolutionary mix of technologies, supply chains, infrastructure, markets, regulations, user practices, and cultural meanings and that transitions come about through dynamic processes, MLP suggests that those processes should be analyzed within and between three different levels, which are: (i) the micro or niche-innovations level; (ii) sociotechnical regimes and (iii) exogenous context or socio-technical landscape (Geels, 2002; Geels, 2018).

The first level consists of small actors supporting novelties based on co-construction, expectations, and visions. These niches, which are flexible and fluid, influence the environment and 
suffer external influence. Radical innovation is assumed to emerge in this micro or niche level (Geels, 2002; Geels \& Schot, 2007) and it can be defined as a socio-technical intervention aiming at leading the transition process. This named socio-technical intervention, resulting from the innovation process, must consider the transition impacts on cultural practices, ecological dynamics, and the stakeholders' opportunities, challenges, and power asymmetries (Valencia et al., 2021).

Radical innovations emerge from the technological niches, and it implies the emergency of new knowledge and products and new communities, networks, and institutional rules (Van de Ven, 1993; Geels et al., 2008). These novelties are, at first, unstable and with low performance, which is why the micro-level acts as an incubation room, protecting novelties from the mainstream market selection. The emergence of these novelties in the so-called protected spaces or incubation rooms, free from mainstream market selection, is essential to foster changes that may enable a broader socio-technical transition (Kemp et al., 1998; Geels \& Schot, 2007; Kivimaa, 2014). This process requires significant changes in culture and behavior and support for new institutional priorities (Köhler et al., 2020). The socio-technical regime, on the other hand, represents institutional structures. Existing elements become aligned, making it dynamically stable in a dominant design, consistent with path dependence and incremental changes. The third level is the exogenous environment. Landscape developments put pressure on the existing regime, opening opportunities for niche innovations. Transitions may occur top-down or bottom-up, meaning the landscape may exert external pressure on the regime level, or niches of deployment may start the process (Geels, 2007; Raven et al., 2016; Geels, 2018; Ismaeel, 2019). Multilevel effects facilitate or obstruct potential pathways to change towards sustainability, depending on the pressures exerted at each level. The literature points out that dynamic capabilities, in turn, can help to align the macro and micro levels of perspective and foster goals at the organizational level (Valencia et al., 2021; Gruchmann et al., 2021). According to Geels \& Schot (2007), empirical levels do not necessarily correspond to analytical levels of the MLP. The analyst should demarcate the practical level object of analysis and, later, operationalize the MLP.

\section{METHODOLOGY}

First, it is required to define what is intended to be accomplished and, later, to describe the findings. The systematic review is a required method for summarizing evidence with precision and reliability. This study aims to explore the state of the literature about socio-technical transitions for sustainability and characterize the multilevel perspective as a framework for the analysis. Therefore, research descriptors were: Sociotechnical Transitions and Multilevel Perspective. The search term to cover the investigated terms is as follows: ("socio-technical transitions" OR "socio-technical systems" OR "sustainability transitions" OR "energy transitions") AND ("MLP" OR "multilevel perspective" OR "multilevel perspective").

Due to the relevance to the area and availability of indexed journals, the ISI, Science Direct, Emerald, Willey, and Scopus databases were searched (Mongeon \& Paul-Hus, 2016), considering only papers published in peer-reviewed journals. Peer-reviewed journal articles tend to demonstrate a more consistent degree of quality than other types of documents (Zheng \& Kouwenberg, 2019). The PRISMA recommendation (Preferred Reporting Items for Systematic reviews and MetaAnalyse) was adopted in this study (Moher et al., 2010 This method specifies four steps to be followed and reported when identifying and extracting information for a literature review: identification, selection, eligibility, and inclusion. Santos and D'Antone (2014) inclusion and exclusion steps and criteria were also considered.

The first stage aimed to identify a set of articles related to the theme. A raw database composed of 990 articles was identified, not aligned with the research theme. No time cut was applied in the search. With the EndNote X7 software, analyzes were performed, and duplicate 
documents were excluded. The retrieved data includes author, names and affiliations, article title, keywords, and abstract. Then, documents with incomplete metadata were evaluated and excluded. Documents other than English were excluded. Other twenty-five documents were recruited by snowballing, which is a method of tracking references (Greenhalgh \& Peacock, 2005).

Given our research question, it was considered that peer-reviewed journal articles tend to demonstrate a more consistent degree of quality than other types of documents (Zheng \& Kouwenberg, 2019). Despite the filter established in the databases, not research papers, but book chapters or conference papers were also excluded. After, from 809 documents, those whose titles or keywords did not align with the research descriptors were excluded. As an inclusion criterion was considered mandatory that the article's content articulate both axes of the research (socio-technical transitions and MLP). Of the remaining papers, all abstracts were read. Methodological choices tend to consider the researcher's subjective views, which is not a devaluation if justified (Ensslin et al., 2010). Due to the researcher's line of study, the content analysis of the abstracts considered research that could contribute to the understanding of energy transitions, even if performed in other sectors. A portfolio of 65 papers was selected for fundamental analysis and qualitative synthesis. It is necessary to consider that the inclusion and exclusion process is not devoid of the researcher's subjectivity, despite the objective criteria adopted in the initial phases. Figure 1, below, illustrates this research process:

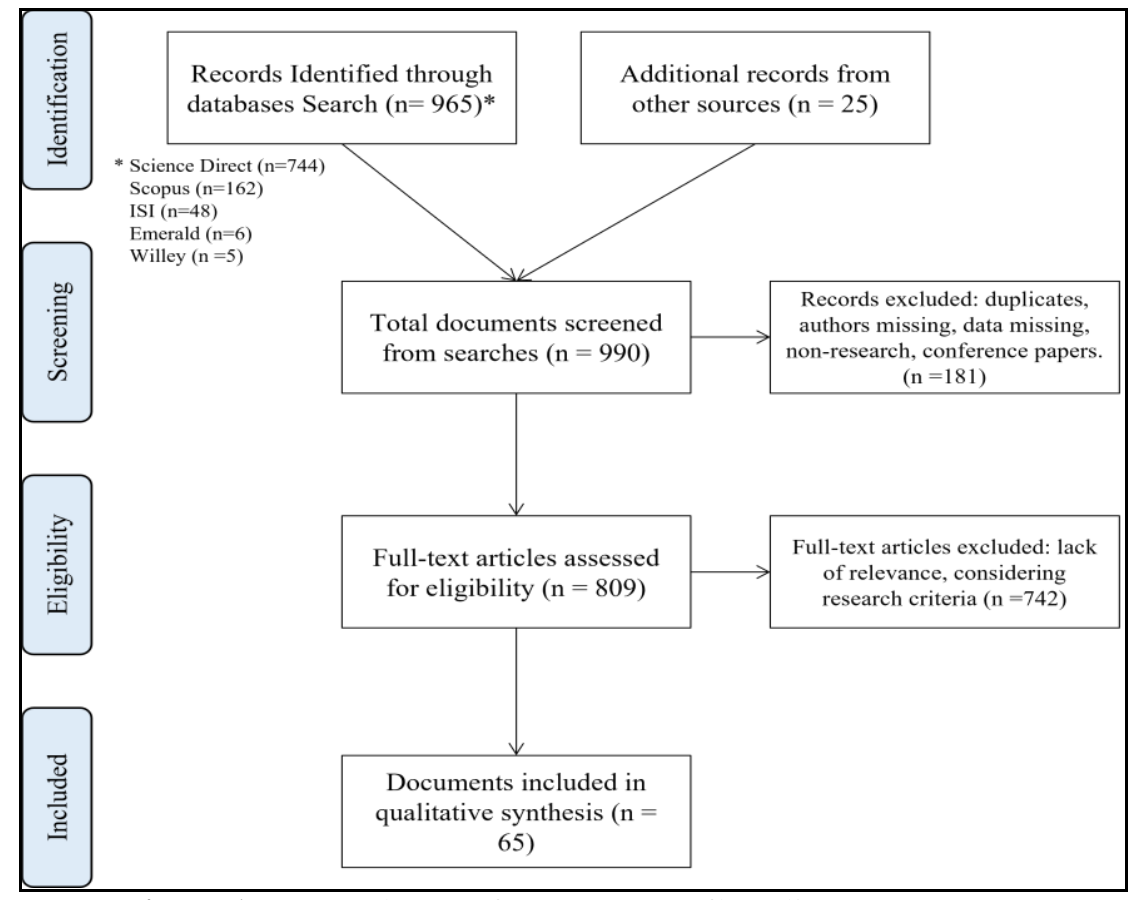

Figure 1- Research Steps from PRISMA flow dia gram.

Source: The authors (2021).

Descriptive data analysis relied on a quantitative approach for topographical and bibliometric analysis. In Excel, descriptive statistics were employed to generate a series of graphs and tables intended to identify patterns and frequency. As for the citation analysis, considering the scope of the research reached more than one database. Data was retrieved from Google Scholar since, due to its coverage, it is a valuable source for analysis in applied social sciences (Prins et al., 2016; Martín-Martín et al., 2018; Nora et al., 2021). The number of times a given document in the review portfolio has been cited by other documents located on scientific databases was examined. The collection of citation numbers was carried out in April 2021. Since citations are accepted to establish scholarly impact, it was performed to help identify influential authors, papers, and 
journals. It is generally considered well-referenced in an article cited more than fifty times (Greenwood \& Meyer, 2008; Santos \& D'Antone, 2014). Another aspect of this analysis is the year of publication. A recently published article with several mentions in the literature deserves to be highlighted.

After this phase of data organization constituting the research corpus, a content analysis was performed to carry out the critical synthesis of the findings. It involves, precisely, a "floating" reading, that is, a first contact with the documents that will be analyzed, their choice, and the elaboration of the indicators that guide the interpretation of the material (Bardin, 2010). Critical synthesis is one of the review methods most widely adopted in applied social science research (Zhang et al., 2019; Zheng \& Kouwenberg, 2019; Tranfield et al., 2003). The last step was to read 65 articles thoroughly, extract the data corresponding to the research questions, understand it, and synthesize concepts and their interrelations.

\section{DESCRIPTIVE ANALYSIS}

These articles come from a wide variety of sources, which points to the interdisciplinary nature of this subject. The keywords variety and the analysis of citations for the journals indicate how the network of relevant literature is developed. The underlining of this section is on answering the following questions: Which journals publish the topic most? What are the journal's main research areas? Where are the corresponding authors located? What are the main interests (keyword analysis) of these studies? How are these works cited in the literature? What is the primary methodological approach?

\subsection{Journals}

The sixty-five articles in this selected portfolio come from nineteen different journals, of which thirteen are published by Elsevier. To assess the impact of journals in the portfolio, SCImago $\mathrm{H}$ Index was used. It provides unrestricted access, is based on a larger source journal database, and focuses on the quality of citations that a journal receives by other journals, rather than the absolute number (Falagas et al., 2008). Table 1 shows the six most redundant journals in the selected portfolio, classified by the largest number of documents in the sample.

Table 1 - Most Redundant Journals in the Selected Portfolio

\begin{tabular}{|c|c|c|c|c|c|}
\hline $\begin{array}{c}\text { Documents in } \\
\text { portfolio }\end{array}$ & Journal & $\begin{array}{c}\text { H Index } \\
\text { (SCImago) }\end{array}$ & $\begin{array}{c}\text { Publisher \& } \\
\text { Coverage }\end{array}$ & Country & Main Areas \\
\hline 17 & Research Policy & 224 & $\begin{array}{c}\text { Elsevier/ } \\
1971-2020\end{array}$ & Netherlands & $\begin{array}{c}\text { Business, Management and Accounting, } \\
\text { Decision Sciences, Engineering }\end{array}$ \\
\hline 12 & $\begin{array}{c}\text { Technological Forecasting } \\
\text { and Social Change }\end{array}$ & 103 & $\begin{array}{c}\text { Elsevier/1970- } \\
2020\end{array}$ & EUA & $\begin{array}{c}\text { Business, Management and Accounting, } \\
\text { Psychology }\end{array}$ \\
\hline 6 & $\begin{array}{c}\text { Energy Research \& Social } \\
\text { Science }\end{array}$ & 49 & $\begin{array}{c}\text { Elsevier/2014- } \\
2020\end{array}$ & $\begin{array}{c}\text { United } \\
\text { Kingdom }\end{array}$ & Energy, Social Sciences \\
\hline 5 & Energy Policy & 197 & $\begin{array}{c}\text { Elsevier/ 1973- } \\
2020\end{array}$ & $\begin{array}{c}\text { United } \\
\text { Kingdom }\end{array}$ & Energy, Environmental Science \\
\hline 5 & $\begin{array}{c}\text { Technology Analysis \& } \\
\text { Strategic Management }\end{array}$ & 64 & $\begin{array}{c}\text { Elsevier/ } \\
1989-2020\end{array}$ & $\begin{array}{c}\text { United } \\
\text { Kingdom }\end{array}$ & $\begin{array}{c}\text { Business, Management and Accounting, } \\
\text { Decision Sciences }\end{array}$ \\
\hline 5 & $\begin{array}{c}\text { Environmental Innovation } \\
\text { and Societal Transitions }\end{array}$ & 42 & $\begin{array}{c}\text { Elsevier/201 1- } \\
2020\end{array}$ & Netherlands & $\begin{array}{c}\text { Energy, Environmental Science, Social } \\
\text { Sciences }\end{array}$ \\
\hline 3 & $\begin{array}{c}\text { Journal of Cleaner } \\
\text { Production }\end{array}$ & 173 & $\begin{array}{c}\text { Elsevier/ 1993- } \\
2020\end{array}$ & $\begin{array}{c}\text { Netherlands } \\
\text { Business, Management and Accounting, } \\
\text { Energy, Engineering, Environmental } \\
\text { Science }\end{array}$ \\
\hline
\end{tabular}

Source: Research data (2021).

As seen, the main areas of prominent journals are Business Management and Social Sciences. However, in many cases, the areas appear combined with others, demonstrating the interdisciplinary nature of the topic. Table 2 presents the seven most influential journals publishing socio-technical transitions and MLP, ranked by their H Index. 
Table 2 - Most Influential Journals by H Index

\begin{tabular}{|c|c|c|c|}
\hline H Index (SCImago) & Journal & Publisher & $\begin{array}{c}\text { Documents in } \\
\text { Portfolio }\end{array}$ \\
\hline 1124 & Science & $\begin{array}{c}\text { American Association for the Advancement of } \\
\text { Science }\end{array}$ & 1 \\
\hline 258 & $\begin{array}{c}\text { Elsevier } \\
\text { Renewable and SustainableEnergy } \\
\text { Reviews }\end{array}$ & Elsevier & 1 \\
\hline 224 & Research Policy & Elsevier & 17 \\
\hline 197 & Energy Policy & Elsevier & 5 \\
\hline 173 & Journal of Cleaner Production & SAGE Publications & 3 \\
\hline 138 & Progress in Human Geography & Elsevier & 1 \\
\hline 121 & Technovation & & 1 \\
\hline
\end{tabular}

Source: Research data (2021).

As for the geographic distribution of journals, the portfolio features four countries, namely: Finland, the United Kingdom, the Netherlands, and the United States. Of these, the United Kingdom and the Netherlands stand out. Nine journals represented in these results are from the United Kingdom. Research Policy is a journal from the Netherlands that has 17 documents in this research portfolio. Also, Technological Forecasting and Social Change, a US journal, has 12 documents in the portfolio. The evolution of this research literature was further analyzed in terms of the longitudinal progression of annual publication volume.

\subsection{Geographic Distribution of Corresponding Authors}

Corresponding authors in this selected portfolio are from sixteen different countries. Most of the corresponding authors are from Europe. In twenty-nine of the sixty-five articles, the corresponding author is from the United Kingdom. It is necessary to consider that some authors are redundant in the portfolio. However, the indicator highlights the development of research in this region. Also worth mentioning are The Netherlands and Germany, as in both cases, six articles have the corresponding author of a researcher from the country. Switzerland then stands out with four articles.

\subsection{Influential Authors and Papers}

Twenty-four of the sixty-five articles that make up the analyzed portfolio have only one author. Nine of them have two authors; eighteen have three, and six have four or more authors. Frank W. Geels stands out as an author in twenty-five articles in the selected portfolio, ten of which are among the fifteen most cited in the portfolio and two among the most cited published in the last five years. The authorship is individual in sixteen of the twenty-five mentioned articles. The twentythree most cited articles in the selection represent $90 \%$ of the citations in the entire portfolio. Notably, there are nine articles with more than 50 citations within five years of publication, demonstrating the current and great academic interest in the topic. Table 3 shows the fifteen most cited articles, their authors, and journals.

Table 3 - InfluentialPapers and Authors ranked by citation number

\begin{tabular}{|c|c|c|c|c|}
\hline Citations & Title & Year & Author & Journal \\
\hline 5976 & $\begin{array}{c}\text { Technological transitions as evolutionary reconfiguration processes: } \\
\text { a multi-level perspective and a case study. }\end{array}$ & 2002 & Geels, F. W. & Research Policy \\
\hline 4692 & Typology of sociotechnical transition pathways & 2007 & Geels, F. W. \& Schot J. & Research Policy \\
\hline 3906 & From sectoral systems of innovation to socio-technical systems. & 2004 & Geels, F. W. & Research Policy \\
\hline 2459 & $\begin{array}{c}\text { Sustainability transitions: An emerging field of research and its } \\
\text { prospects }\end{array}$ & 2012 & $\begin{array}{c}\text { Markard, J.; Raven, \& } \\
\text { Truffer, B. }\end{array}$ & Research Policy \\
\hline 2255 & $\begin{array}{c}\text { The multi-level perspective on sustainability transitions: Responses } \\
\text { to seven criticisms. }\end{array}$ & 2011 & Geels, F. W. & $\begin{array}{c}\text { Environmental Innovation } \\
\text { and Societal Transitions }\end{array}$ \\
\hline 1868 & $\begin{array}{c}\text { Strategic niche management and sustainable innovation journeys: } \\
\text { theory, findings, research agenda, and policy }\end{array}$ & 2008 & Schot J \& Geels, F. W. & $\begin{array}{c}\text { Technology Analy sis \& } \\
\text { Strategic Management }\end{array}$ \\
\hline 1713 & $\begin{array}{c}\text { Innovation studies and sustainability transitions: the allure of the } \\
\text { multi-level perspective and its challenges. }\end{array}$ & 2010 & $\begin{array}{c}\text { Smith, A.; Vob, J.P. \& } \\
\text { Grin J. }\end{array}$ & Research Policy \\
\hline
\end{tabular}




\begin{tabular}{|c|c|c|c|c|}
\hline 1583 & $\begin{array}{c}\text { Ontologies, socio-technical transitions (to sustainability), and the } \\
\text { multi-level perspective }\end{array}$ & 2010 & Geels, F. W. & Research Policy \\
\hline 1390 & $\begin{array}{c}\text { Technological innovation systems and the multi-level perspective: } \\
\text { towards an integrated framework. }\end{array}$ & 2008 & $\begin{array}{l}\text { Markard, J. \& Truffer, } \\
\text { B. }\end{array}$ & Research Policy \\
\hline 1096 & $\begin{array}{c}\text { Regime Resistance against Low-Carbon Transitions: Introducing } \\
\text { Politics and Power into the Multi-Level Perspective }\end{array}$ & 2014 & Geels, F. W. & Theory, Culture \& Society \\
\hline 1008 & Toward a spatial pers pective on sustainability transitions. & 2012 & $\begin{array}{l}\text { Coenen, L.; } \\
\text { Benneworth, P. \& } \\
\text { Truffer. B. } \\
\end{array}$ & Research Policy \\
\hline 983 & $\begin{array}{l}\text { Processes and patterns in transitions and system innovations: } \\
\text { Refining the co-evolutionary multi-level perspective }\end{array}$ & 2005 & Geels, F. W. & $\begin{array}{l}\text { Technological Forecasting } \\
\text { and Social Change }\end{array}$ \\
\hline 935 & $\begin{array}{l}\text { Translating Sustainabilities between Green Niches and Socio- } \\
\text { Technical Regimes }\end{array}$ & 2007 & Smith, A. & $\begin{array}{l}\text { Technology Analysis \& } \\
\text { Strategic Management }\end{array}$ \\
\hline 916 & $\begin{array}{l}\text { The dynamics of transitions in socio-technical systems: A multi-level } \\
\text { analysis of the transition pathway from horse-drawn carriages to } \\
\text { automobiles (1860-1930) }\end{array}$ & 2006 & Geels, F. W. & $\begin{array}{l}\text { Technology Analysis \& } \\
\text { Strategic Management }\end{array}$ \\
\hline 911 & $\begin{array}{l}\text { The ongoing energy transition: Lessons from a socio-technical, multi- } \\
\text { level analysis of the Dutch electricity system }(1960-2004)\end{array}$ & 2007 & $\begin{array}{l}\text { Verbong, G. \& Geels, } \\
\text { F. W. }\end{array}$ & Energy Policy \\
\hline
\end{tabular}

Source: Research data (2021).

One indication of impact, as previously mentioned, is citation numbers. Most papers are considered relevant if they are cited more than 50 times, and their life span of influence is usually brief (Greenwood \& Meyer, 2008). Table 4 shows nine recent articles, within less than five years of publication, with a significant number of citations.

Table 4 - Most cited articles within five years of publication

\begin{tabular}{|c|c|c|c|c|}
\hline Title & Year & Author & Journal & Citations \\
\hline $\begin{array}{c}\text { Creative destruction or mere niche support? Innovation policy mixes } \\
\text { for sustainability transitions. }\end{array}$ & 2016 & $\begin{array}{l}\text { Kivimaa, P. \& } \\
\text { Kern, F. }\end{array}$ & Research Policy & 564 \\
\hline $\begin{array}{l}\text { The enactment of socio-technical transition pathways: A } \\
\text { reformulated typology and a comparative multi-level analysis of the } \\
\text { German and UK low-carbon electricity transitions (1990-2014) }\end{array}$ & 2016 & Geels, F. W. et al. & Research Policy & 519 \\
\hline An agenda for sustainability transitions research: State of the art & 2019 & Köhler et al. & $\begin{array}{c}\text { Environmental } \\
\text { Innovation and Societal } \\
\text { Transitions }\end{array}$ & 492 \\
\hline Sociotechnical transitions for deep decarbonization & 2017 & Geels, F. W. et al. & Science & 386 \\
\hline $\begin{array}{l}\text { Disruption and low-carbon system transformation: Progress and new } \\
\text { challenges in socio-technical transitions research and the Multi-Level } \\
\text { Perspective }\end{array}$ & 2018 & Geels, F. W. & $\begin{array}{l}\text { Energy Research \& } \\
\text { Social Sciences }\end{array}$ & 200 \\
\hline $\begin{array}{l}\text { Socio-technical transitions and policy change - Advocacy coalitions } \\
\text { in Swis energy policy }\end{array}$ & 2016 & $\begin{array}{l}\text { Markard, J.; } \\
\text { Suter, M. \& } \\
\text { Ingold, K. }\end{array}$ & $\begin{array}{c}\text { Environmental } \\
\text { Innovation and Societal } \\
\text { Transitions }\end{array}$ & 200 \\
\hline $\begin{array}{c}\text { Business models as drivers of the low carbon power system } \\
\text { transition: a multi-level perspective }\end{array}$ & 2016 & $\begin{array}{l}\text { Wainstein, M.E. } \\
\text { \& Bumpus, A.G. }\end{array}$ & $\begin{array}{l}\text { Journal of Cleaner } \\
\text { Production }\end{array}$ & 125 \\
\hline $\begin{array}{l}\text { Socio-technical transitions to sustainability: a review of criticisms } \\
\text { and elaborations of the Multi-Level Perspective }\end{array}$ & 2019 & Geels, F. W. & $\begin{array}{l}\text { Current Opinion in } \\
\text { Environmental } \\
\text { Sustainability }\end{array}$ & 92 \\
\hline
\end{tabular}

Source: Research data (2021).

We highlight Kivimaa \& Kern (2016), with 564 citations, published in the "Research Policy." The authors argue that sociotechnical transitions imply the development of disruptive innovations and policies aimed at broader change in sociotechnical systems. They propose that ideally, policy mixes for transitions should include elements of "creative destruction," involving both policies aimed at "creating" the new and "destabilizing" the old. According to Kivimaa \& Kern (2016), the main idea of the MLP is that transitions come about through interactions between three different levels and that top-down landscape pressures. Hence, bottom-up developments of several emerging niches may lead to the destabilization of incumbent regimes. They point out that the existing academic literature on socio-technical transitions to sustainability recognizes that governing transitions is a political project in which the direction of travel and means are often highly contested (Kivimaa \& Kern, 2016). It is also worth mentioning the article by Köhler et al. (2019) with 492 citations, accepted in January 2019 and published in the journal "Environmental 
Innovation and Societal Transitions." The authors provide an extensive review and an updated research agenda for socio-technical transitions, classified into nine principal themes.

\subsection{Keywords}

In the selected portfolio, 299 keywords were raised, among which 24 terms are redundant. Among the keywords with co-occurrence, the term multilevel perspective was redundant in 28 articles in the portfolio, with spelling variations (multilevel perspective, multilevel-perspective or multilevel perspective). In analyzing the co-occurrence of keywords, there is an excellent centrality of themes related to sustainability in transition studies, mainly due to the search terms, to energy. The verified terms corroborate the adherence of the selected articles to the research axes and descriptors.

\subsection{Methodological Approach}

Qualitative research stands out in the portfolio regarding the methodological approach, as $57 \%$ of papers used this approach. Among the other articles, 5\% used mixed methods and 37\% theoretical. The search presented only one quantitative article (Hirt et al., 2021), which will be better addressed in the literature discussion.

There was a strong trend towards the adoption of qualitative research methods, with emphasis on the investigative strategy of content analysis, discourse analysis, case study (e. g.: Levidow \& Upham, 2017; Lee et al., 2020); multiple case studies (e.g., Marx et al., 2015) and documentary longitudinal case studies (e.g., Geels, 2007; Geels, 2009; Jørgensen, 2012; Geels, 2016; Roberts \& Geels, 2019; Wilkinson et al., 2020). Some combine qualitative and quantitative approaches (Köhler et al., 2020; Geels et al., 2020). Also, many theoretical articles were found (e.g., Geels \& Schot, 2007; Geels, 2011; Markard et al., 2012; Köhler et al., 2019; Batinge et al., 2019). This vast presence of theoretical articles in prominent journals may indicate the academic perception of the need to deepen transition's theory.

\section{LITERATURE DISCUSSION}

This study emphasizes socio-technical transitions, contextualizes the issue of sustainable development, and aims to characterize MLP as an analytical framework. The 65 papers, considering the research axes defined in this article, all mention the framework of the multilevel perspective for their analysis of socio-technical transitions. The review covers more than twenty-five years of transitions studies. The idea is to structure the research discussion according to its direction. By synthesizing those articles and analyzing the main concepts and their interrelationships, this section answers the research question.

\subsection{Critical Synthesis}

Different terms and concepts are used in the literature to signify and objectify what sociotechnical transition is. Going through these definitions, we identified that socio-technical transitions are multi-dimensional, multi-actor, long-term, and coevolutionary processes. Processes are characterized by path dependency, resistance to change, uncertainties, and disagreements between incumbent and new actors. Technology, in a way, is a tool in the transition process. New technology is usually seen as something from the outside. A transition in the regime level must activate its adaptive capacity to receive new technologies, responding to pressures that may affect it (Rip \& Kempt, 1998; Jacobsson \& Johnson, 2000; Unruh, 2000; Berkhout, 2002; Geels, 2002; Geels, 2005a; Smith et al., 2005; Geels, 2005b; Smith, 2007).

The systemic dimension of transitions and the struggle between stability and change are central to the MLP, characterized by the interface of different degrees of structuring (Köhler et al., 
2019). As a framework to analyze transitions, MLP brings different visions of interactions between its three levels. Some state transitions occur when the coevolutionary dynamics at these three levels connect and reinforce each other (Geels, 2006b). Others examine how niches and regimes interact and are interdependent, considering translations between niches and regimes (Smith, 2007). Besides, some studies emphasize niche-empowerment to adjust existing regimes (Smith \& Raven, 2012; Raven et al., 2016), interactions between multiple regimes (Geels, 2007), and active resistance to transitions (Geels, 2014). MLP also supports the assertion that sustainable development leads to a reassessment of innovation and technological change (Smith et al., 2010) and allows addressing the duration and acceleration of sustainability transitions (Kanger, 2021). In this sense, the multilevel perspective was used to explore contexts, processes, policies, institutions, and interactions that affect microgrid adoption (Ajaz \& Bernell, 2021).

There is, moreover, the use of the multilevel perspective to support the discussion of clashes between different political views on the transition process, the pressure of the actors for the adoption of one or the other path, and the role of the intermediary actors in this process of rupture or adjustment of the regime (Kivimaa, 2014; Hess, 2016; Stirling, 2014; Turnheim \& Nykvist, 2019). In addition, MPL upholds the study of cooperation between incumbents and new entrants (Geels et al., 2016). The structural rules are restrictive, informing the acts' legitimacy and simultaneously creating an environment of trust and predictability that allows the development of actions (Geels, 2004; Geels, 2006). Geels \& Schot (2007) bring the theory of structuring by Giddens (1984) to explain the role of actors in the structure of rules that they reproduce through their actions. Actors are passive followers of rules and, at the same time, active creators of rules.

It is possible to state that the first generation of studies was focused on emerging innovations and the resistance of established structures to changes in the socio-technical regime. Unruh (2002), for example, states that the institutional technocratic complex generates blockages (or lock-ins) to changes in the system. Geels (2002) brings concepts and insights from evolutionary economics and technology studies to transition studies. Such studies resulted in an MLP for technological transitions. Two views of evolution are combined, namely: (i) evolution as a process of variation, selection, and retention, (ii) evolution as a process of unfolding and reconfiguration. When innovation enters the markets, the actors of the current regime defend themselves and invest in improvements - so-called by Geels \& Schot (2007) the "sailing ship effect." Market competition and power struggle influence competition between incumbents and new entrants. If innovation replaces the old technology, it leads to indirect effects and broader changes in the socio-technical regime (Geels \& Schot, 2007; Geels et al., 2008). Geels \& Schot (2007) argue that, although it does not always show in case studies, the agency is always present in the MLP because its levels provide different degrees and kinds of structuration to local practices. The MLP is usually a global model that maps the entire transition process, which is why it may not emphasize each actor. However, it allows the analyst to expand the look to the actors, considering that they connect processes at different levels in their cognitions and activities. The dynamic of MLP is not mechanical, and different groups socially construct it that pressure, negotiate, and form coalitions. With its attention to the interactions among niches, regimes, and landscapes, the MLP perspective provides narrative explanations regarding patterns resulting from interactions (Geels \& Schot, 2007).

The second generation comes with an emphasis on accelerating socio-technical changes. At its heart is innovation. There is a need to develop new industries, fundamental transformations in existing sectors, and long-term vision (Smith, 2007; Markard \& Truffer, 2008; Markard et al., 2009; Smith et al., 2010). The literature has evolved over the years. The institutional theory perspective was incorporated into transition studies and made it possible to explore how actors can influence the movement towards sustainable development. Developing and nurturing alternative technological interventions designed to mitigate poverty and social exclusion, promote de-carbonization, and prevent harmful effects of climate change (Lawhon \& Murphy, 2012; Geels et al., 2016; Geels et 
al., 2017). Fuenfschilling \& Truffer (2014) work from an MLP in the light of Institutional Theory, considering the organizational field as an environment of institutional processes and sharing systems of ordinary meaning. In this context, the social structures that guide actions in the field of organizational interaction can be regulatory (formal laws and standards), normative (rules of conduct, moral values), or cognitive-cultural (beliefs, understandings, interpretation). The authors use institutional logic to characterize the content of various structural elements present in a sociotechnical system, tracking conflicts and contradictions between them. They state that the practical occurrence of the transition presupposes a process of institutionalization of change (Markard et al., 2012; Fuenfschilling \& Truffer, 2014).

Studies have emerged in the last ten years that point out potential weaknesses and suggest adjustments to the MLP framework. Sorrel (2018), for example, identifies and assesses the explicit and implicit philosophical assumptions underlying the MLP. These include assumptions about the nature of reality (ontology), the status of statements about that reality (epistemology), and the appropriate choice of research methods. The paper assesses the consistency of these assumptions with the philosophical tradition of critical realism and uses it to highlight several potential MLP weaknesses. It concludes, though, that the flexibility of MLP provides room for proposing an alternative and critical realistic interpretation of socio-technical systems. The next generation of studies focuses on the grand challenges faced today. Wainstein \& Bumpus (2016), for example, adopt MLP to explain actor dynamics in the energy transition lock-in. Other studies also congregate sustainable development challenges and sustainability transitions with the MLP (Coenen et al., 2012; Kivimaa \& Kern, 2016; Vähäkari et al., 2020; Pilloni et al., 2020; Zwartkruis et al., 2020). Coenen et al. (2012) bring about the geographic unevenness of transition processes. Authors demonstrate concern about the lack of attention for the spatial dimensions of sustainability transitions in most studies. They argue that there are two inter-related problems: institutional embeddedness of socio-technical development processes within specific territorial spaces and an explicit multi-scalar conception of socio-technical trajectories.

Kivimaa \& Kern (2016) argue that an area in which policy combinations are significant in the field of sustainability transitions. The paper recognizes that transitions imply policies that aim at a broader change in socio-technical systems. It proposes that these policy combinations for transitions include elements of "creative destruction," involving both policies aimed at "creating" the new and "destabilizing" the old, as articulated by the MLP. Also, it develops a new analytical framework, including the two dimensions of policy combination ('creation' and 'destruction'), broadening the approach to the functions of the technological innovation system. Recently, Geels (2020) stated that the MLP is a prominent framework for understanding socio-technical transitions, but its microfoundations have remained underdeveloped. It seeks to develop the theoretical micro-foundations of MLP, which are rooted in the Social Construction of Technology, evolutionary economics, and neoinstitutional theory. It analytically reviews the three theories, focusing on:

1. the relevance of each theory to the transitions and MLP,

2. the conceptualization of the agency theory,

3. The criticisms of each theory and subsequent conceptual elaborations (which set the stage) for potential crossings between them).

It articulates a multi-dimensional model of agency, which provides a relational and procedural conceptualization of the continuous trajectories in which the actors are inserted. It is because sociotechnical transitions are evolutionary processes and, more than that, are interpretative and sociocultural processes.

Vähäkari et al. (2020), pursuing to advance on the frontier of knowledge, suggests an essential framework to link sustainability studies and MLP. Authors propose that there are various co-benefits in creating convergence between the two fields of study. They also assert that the MLP framework gives a structure to the systemic dynamics in societal change providing methods to 
construct alternative pathways to societal transitions, contributing to a better understanding of the dynamics of change for more sustainable futures. Also connecting sustainability transitions and MLP, Pilloni et al. (2020) use the framework for an in-depth examination into drivers and barriers to biogas technology. The authors introduce the social niche concept, which plays the agency's role that embodies individuals' level and bridges social practices to the regime.

In a similar path, Zwartkruis et al. (2020) combine three perspectives with studying the role of agricultural nature conservation in the Dutch land-use domain for achieving internationally agreed climate and biodiversity targets, which are Multilevel Perspective (MLP), Initiative Based Learning (IBL) and Integrated Assessment Modelling (IAM). The MLP's role in this framework is to provide insight into how agricultural nature conservation has affected or changed the existing nature and agricultural regimes.

Mohamed et al. (2020) adopt MLP and address stakeholders' engagement and connection during transition processes. The paper combines the strength of the global value chain (GVC) and national innovation system (NIS) using a multi-level perspective (MLP) to create a new framework that could reveal the interconnections between the actors. The global system of innovation (GSI) framework is introduced to point out the key players participating in the transition. In search, as well, of an expanded framework of analysis, Miremadi (2020) states that there is a clear difference between the literature of multi-level perspective with an original focus in north Europe with reflexive governance and the new literature which documents the sustainability transition in nonreflexive societies. The author supports the coupling of Multilevel Perspective and Causal Layered Analysis to find facts that, in his view, would have been hidden if the research were confined to the MLP. Despite the criticism and complementary approaches, it is fair to argue that MLP remains the most applied framework to address large-scale infra-structural socio-technical change (Geels \& Schot, 2007; Spinardi \& Slayton, 2015; Roberts \& Geels, 2019; Batinge et al., 2019).

\subsection{Future Perspectives}

MPL still permits addressing the rise of new technology systemically and holistically (Batinge et al., 2019; Hirt et al., 2021). The level of analysis issue lingers on as an essential line of research. It remains relatively unexplored in the scholarly literature how short-term changes at the micro-level (or niche-innovation level) relate with a transformative long-term change at the system level (Hodson et al., 2017; Ehnert et al., 2018; Köhler et al., 2019; Strambach \& Pflitsch, 2020). Pilloni et al. (2020) assert the importance of exploring the role of social niches and niche strategic management in transition studies in poor contexts. Working at the micro-level contributes to transitions at the macro-level (Köhler et al., 2019; Geels, 2020), which is why qualitative research can contribute to better understanding socio-technical transitions in contemporary times, performing case studies allowing to oppose both levels. Understanding conflicts between actors in different levels, and their interests, allows a better assessment of the conditions for the socio-technical transitions to materialize. Transformative innovations are constantly under pressure from and pressuring established institutions, while new actors are lobbying for alternative socio-technical configurations. Despite the manifest interdisciplinarity of the theme, the social dimension has a limited emphasis on literature (Luchsinger, 2009; Lieu et al., 2020). MLP allows the combination of perspectives to broaden its outlook. It appears, therefore, that there is room for theoretical contribution from other fields in the social sciences, such as, for example, the aggregate of organizational theories (Farla et al., 2012; Geels, 2018). Besides, MLP can aggregate to the field of future studies, providing an understanding of historical development processes (Hofman \& Elzen, 2010; Vähäkari et al., 2020).

Quantitative methods are not usual in the field so that only one article in this portfolio represented this approach (Hirt et al., 2021). However, they may provide further support for regime 
description and differentiation in the future. Therefore, seems to be room for eventual scale development and linkage between MLP framework and quantitative statistical methods. Nevertheless, the qualitative approach remains prominent because it favors the addition of contextual richness, involving real-world actors, systems, and transitions, demonstrating who potentially gains or loses something when innovations arise and are implemented by elucidating the role of actors in the transition paths (Smith \& Stirling, 2018). As transitions are not random or linear, it is required to comprehend the context in which developments occur (Verbong \& Geels, 2007; Markard et al., 2012), another reason why the qualitative approach is preferred. As the temporal framework expands, historical perspectives may allow depth in analysis. Especially regarding the energy sector and transitions to renewable sources, key actors' economic and political struggles, such as state-owned companies, have a determining role in the transition paths (Markard, 2018). The critical synthesis demonstrates a tendency to combine models and theories to account for the complexity of current socio-technical transition studies (e.g., Kivimaa \& Kern, 2016; Miremadi, 2020; Vähäkari et al., 2020). The MLP is usually a global model that does not explicitly focus on the actors at each level of analysis (Geels \& Schot, 2007). The aggregate of organizational theories, such as the Stakeholders Theory, combined with the framework under consideration, can reveal the vital perspective of the actors involved in the process.

\section{CONCLUSIONS}

This paper provided an overview of existing research on socio-technical transitions and MLP. As seen, there is a tendency to combine approaches for developing more complex frameworks, but without leaving out the multi-level perspective.

This trend of combining approaches for expanding the framework may demonstrate, on the one hand, a deficiency of the classic MLP to face today's challenges. On the other hand, an expansion of the scope of the framework to other research fields that were not considered is a fact that would demonstrate the relevance and robustness of the model initially proposed. In addition, MLP is constantly changing, and seminal authors continue to research and add new nuances to the perspective. We believe that despite criticisms made to MLP, it is still an essential framework for transition studies. It is highly flexible, constantly evolving, and can be adapted to reason the complexity of the current reality.

Qualitative methods are the most used since they allow a deeper understanding of this interdisciplinary, complex, dynamic theme, which still requires further development of its fundamental concepts. In recent times, this dynamic evolution of theory suggests that the constructs need to be clearer to support suitable quantitative studies. The MLP framework can significantly help understand the phenomena of socio-technical transitions in Brazil and Latin America, especially regarding the social focus. The historicity of the processes is exceptionally relevant for understanding the pressures exerted at each level of analysis. The socio-technical transitions are path-dependent and rely on resources, territory, and culture in each country. Reconciling the MLP with other theories and adapting it to each reality, outlining local institutions, is essential to advance the frontier of knowledge on the subject. Regarding future studies, we suggest that theories of strategy and organizational be brought to the field of socio-technical transitions to, combined with MLP, provide a greater understanding of the relationships between the actors, the role of these actors, and the conflicts of interest that impact the transition paths in different levels. 


\section{REFERENCES}

Ajaz, W., \& Bernell, D. (2021). Microgrids and the transition toward decentralized energy systems in the United States: A Multi-Level Perspective. Energy Policy, 149, 112094.

Batinge, B., Musango, J. K., \& Brent, A. C. (2019). Sustainable energy transition framework for unmet electricity markets. Energy Policy, 129, 1090-1099.

Bardin, L. (2010). Análise de conteúdo. 4. ed. Lisboa: Edições70.

Berkhout, F. (2002). Technological regimes, path dependency and the environment. Global Environmental Change, 12(1), 1-4.

Binz, C., Truffer, B., \& Coenen, L. (2014). Why space matters in technological innovation systems-Mapping global knowledge dynamics of membrane bioreactor technology. Research Policy, 43(1), 138-155.

Coenen, L.; Benneworth, P.; Truffer, B. (2012). Toward a spatial perspective on sustainability transitions. Research Policy, v. 41, n. 6, 968-979.

Ehnert, F., Kern, F., Borgström, S., Gorissen, L., Maschmeyer, S., \& Egermann, M. (2018). Urban sustainability transitions in a context of multi-level governance: A comparison of four European states. Environmental Innovation \& Societal Transitions, 26, 101-116.

Ensslin, L., Ensslin, S. R., Lacerda, R. T., \& Tasca, J. E. (2010). ProKnow-C, knowledge development process-constructivist. Processo técnico com patente de registro pendente junto ao INPI. Brasil, 10(4), 2015.

Falagas, M. E., Kouranos, V. D., Arencibia-Jorge, R., \& Karageorgopoulos, D. E. (2008). Comparison of SCImago journal rank indicator with journal impact factor. The FASEB journal, 22(8), 2623-2628.

Farla, J., Markard, J., Raven, R., Coenen, L. (2012). Sustainability transitions in the making. A closer look at actors, strategies and resources. Technological Forecasting \& Social Change 79 (6), 991-998.

Forbord, M., \& Hansen, L. (2020). Enacting sustainable transitions: A case of biogas production and public transport in Trøndelag, Norway. Journal of Cleaner Production, 254.

Fuenfschilling, L., \& Truffer, B. (2014). The structuration of socio-technical regimes-Conceptual foundations from institutional theory. Research Policy, 43(4), 772-791.

Geels, F. W. (2002). Technological transitions as evolutionary reconfiguration processes: a multilevel perspective and a case study. Research Policy, v. 31, 1257-1274.

Geels, F.W. (2004). From sectoral systems of innovation to socio-technical systems: Insights about dynamics and change from sociology and institutional theory. Research Policy, 33(6-7), 897-920. 
Geels, F. W. (2005a). Processes and patterns in transitions and system innovations: Refining the coevolutionary multi-level perspective. Technological Forecasting \& Social Change, 72(6), 681-696.

Geels, F. W. (2005b). The dynamics of transitions in socio-technical systems: a multi-level analysis of the transition pathway from horse-drawn carriages to automobiles (1860-1930). Technology Analysis \& Strategic Management, 17(4), 445-476.

Geels, F. W. (2006). Co-evolutionary and multi-level dynamics in transitions: the transformation of aviation systems and the shift from propeller to turbojet (1930-1970). Technovation, 26(9), 9991016.

Geels, F. W. (2007). Analysing the breakthrough of rock 'n'roll (1930-1970) Multi-regime interaction and reconfiguration in the multi-level perspective. Technological Forecasting \& Social Change, 74(8), 1411-1431.

Geels, F. W., \& Kemp, R. (2007). Dynamics in socio-technical systems: Typology of change processes and contrasting case studies. Technology in Society, 29(4), 441-455.

Geels, F. W., \& Schot, J. (2007). Typology of sociotechnical transition pathways. Research Policy, 36(3), 399-417.

Geels, F. W., Hekkert, M. P., \& Jacobsson, S. (2008). The dynamics of sustainable innovation journeys. Editorial. Technology Analysis \& Strategic Management, vol. 20, N. 5, September 2008, 521-53, Routledge, Taylor \& Francis Group.

Geels, F. W. (2009). Foundational ontologies and multi-paradigm analysis, applied to the sociotechnical transition from mixed farming to intensive pig husbandry (1930-1980). Technology Analysis \& Strategic Management, 21(7), 805-832.

Geels, F. W. (2010). Ontologies, socio-technical transitions (to sustainability), and the multi-level perspective. Research Policy, 39 (4), 495-510.

Geels, F. W. (2012). A socio-technical analysis of low-carbon transitions: introducing the multilevel perspective into transport studies. Journal of Transport Geography, 24, 471-482.

Geels, F. W. (2014). Reconceptualising the co-evolution of firms-in-industries and their environments. Developing an inter-disciplinary Triple Embeddedness Framework. Research Policy, 43 (2), 261-277.

Geels, F. W., Kern, F., Fuchs, G., Hinderer, N., Kungl, G., Mylan, J., \& Wassermann, S. (2016). The enactment of socio-technical transition pathways: a reformulated typology and a comparative multi-level analysis of the German and UK low-carbon electricity transitions (1990-2014). Research Policy, 45(4), 896-913.

Geels, F. W. Sovacool, B. K., Schwanen, T., Sorrell, S. (2017). Sociotechnical transitions for deep decarbonization. Science, v. 357, n. 6357, 1242-1244.

Geels, F. W. (2018). Disruption and low-carbon system transformation: Progress and new challenges in socio-technical transitions research and the Multi-Level Perspective. Energy Research \& Social Science, v. 37, p. 224-231. 
Geels, F. W. (2020). Micro-foundations of the multi-level perspective on socio-technical transitions: developing a multi-dimensional model of agency through crossovers between social constructivism, evolutionary economics, and neo-institutional theory. Technological Forecasting \& Social Change, v. 152, p. 1-15, mar.

Geels, F. W., McMeekin, A., \& Pfluger, B. (2020). Socio-technical scenarios as a methodological tool to explore social and political feasibility in low-carbon transitions: Bridging computer models and the multi-level perspective in UK electricity generation (2010-2050). Technological Forecasting \& Social Change, 151, 119258.

Greenhalgh, T., Peacock, R. (2005). Effectiveness and efficiency of search methods in systematic reviews of complex evidence: audit of primary sources. BMJ 331 (7524), 1064.

Greenwood, R.; Meyer, R. E. (2008). Influencing Ideas: A celebration of Di Maggio and Powell. Journal of Management Inquiry, v. 17, n. 4, p.258-264, dez.

Gruchmann, T.; Timmer, V.; Gold, S.; Geßner, C. (2021). Dynamic capabilities for sustainable change in the food processing industry: a multilevel perspective. Journal Of Cleaner Production, v. 311, p. 127534.

Hess, D. J. (2016). The politics of niche-regime conflicts. Distributed solar energy in the United States. Environmental Innovation \& Societal Transitions, 19, 42-50.

Hirt, L. F., Sahakian, M., \& Trutnevyte, E. (2021). What socio-technical regimes foster solar energy champions? Analysing uneven photovoltaic diffusion at a subnational level in Switzerland. Energy Research \& Social Science, 74, 101976.

Hodson, M., Geels, F. W., \& McMeekin, A. (2017). Reconfiguring urban sustainability transitions, analysing multiplicity. Sustainability, 9(2), 299.

Hofman, Peter S. \& Elzen, Boelie. (2010) Exploring system innovation in the electricity system through sociotechnical scenarios. Technology Analysis \& Strategic Management. Volume 22, 2010, Issue 6, Pp. 653-670.

Ismaeel, Muatasim. (2019). Transformation Toward Clean Energy in the Middle East: a multilevel perspective. Understand ing Complex Systems, p. 309-321, Springer International Publishing.

Jacobsson, S., \& Johnson, A. (2000). The diffusion of renewable energy technology: an analytical framework and key issues for research. Energy Policy, 28(9), 625-640.

Jørgensen, U. (2012). Mapping and navigating transitions-The multi-level perspective compared with arenas of development. Research Policy, 41(6), 996-1010.

Kanger, L. (2021). Rethinking the Multi-level Perspective for energy transitions: From regime lifecycle to explanatory typology of transition pathways. Energy Research \& Social Science, 71, 101829. 
Kemp, R., Schot, J., Hoogma, R., 1998. Regime shifts to sustainability through processes of niche formation: the approach of strategic niche management. Technology Analysis \& Strategic Management, v. 10, 175-196.

Kivimaa, P. (2014). Government-affiliated intermediary organisations as actors in system-level transitions. Research Policy, 43 (8), 1370-1380.

Kivimaa, P.; Kern, F. (2016). Creative destruction or mere niche support? Innovation policy mixes for sustainability transitions. Research Policy, v. 45, n. 1, p. 205-217.

Köhler, J., Geels, F. W., Kern, F., Markard, J., Onsongo, E., Wieczorek, A. \& Wells, P. (2019). An agenda for sustainability transitions research: State of the art and future directions. Environmental Innovation \& Societal Transitions, 31, 1-32.

Köhler, J., Turnheim, B., \& Hodson, M. (2020). Low carbon transitions pathways in mobility: Applying the MLP in a combined case study and simulation bridging analysis of passenger transport in the Netherlands. Technological Forecasting \& Social Change, 151, 119314.

Lachman, D. A. (2013). A survey and review of approaches to study transitions. Energy Policy, v. 58, p. 269-276.

Lawhon, M., \& Murphy, J. T. (2012). Socio-technical regimes and sustainability transitions: Insights from political ecology. Progress in Human Geography, 36(3), 354-378.

Lee, T., Glick, M. B., \& Lee, J. H. (2020). Island energy transition: Assessing Hawaii's multi-level, policy-driven approach. Renewable \& Sustainable Energy Reviews, 118, 109500.

Levidow, L., \& Upham, P. (2017). Linking the multi-level perspective with social representations theory: Gasifiers as a niche innovation reinforcing the energy-from-waste (EfW) regime. Technological Forecasting \& Social Change, v. 120, 1-13.

Lieu, J., Sorman, A. H., Johnson, O. W., Virla, L. D., \& Resurrección, B. P. (2020). Three sides to every story: Gender perspectives in energy transition pathways in Canada, Kenya and Spain. Energy Research \& Social Science, 68, 101550.

Luchsinger, G. (2009). Climate Justice for a Changing Planet: A Primer for Policy Makers and NGOs. NY: NGLS, United Nations.

Markard, J., Truffer, B. (2008). Technological innovation systems and the multi-level perspective. Towards an integrated framework. Research Policy, 37 (4), 596-615.

Markard, J., Stadelmann, M., \& Truffer, B. (2009). Prospective analysis of technological innovation systems: Identifying technological and organizational development options for biogas in Switzerland. Research Policy, 38(4), 655-667.

Markard, J.; Raven, R. \& Truffer, B. (2012). Sustainability transitions: An emerging field and its prospects. Research Policy, v. 41, 955-967.

Markard, J. (2018). The next phase of the energy transition and its implications for research and policy. Nature Energy, 3(8), 628-633. 
Martín-Martín, Alberto et al. (2018). Google Scholar, Web of Science, and Scopus: A systematic comparison of citations in 252 subject categories. Journal of Informetrics, v. 12, n. 4, 1160-1177.

Marx, R., de Mello, A. M., Zilbovicius, M., \& de Lara, F. F. (2015). Spatial contexts and firm strategies: applying the multilevel perspective to sustainable urban mobility transitions in Brazil. Journal of Cleaner Production, 108, 1092-1104.

Miremadi, T. (2020). Coupling multilevel perspective with causal layered analysis on non-reflexive societies the case of socio-technical system of car fuel in Iran. Technological Forecasting \& Social Change, 155, 120029.

Mohamad, M., \& Songthaveephol, V. (2020). Clash of titans: The challenges of socio-technical transitions in the electrical vehicle technologies-the case study of Thai automotive industry. Technological Forecasting \& Social Change, 153, 119772.

Moher, D., Liberati, A., Tetzlaff, J., \& Altman, D. G. (2010). Preferred reporting items for systematic reviews and meta-analyses: the PRISMA statement. International Journal of Surgery, v. 8(5), 336-341.

Mongeon, P., \& Paul-Hus, A. (2016). The journal coverage of Web of Science and Scopus: a comparative analysis. Scientometrics, 106(1), 213-228.

Nora, G.A. M. et al. (2021). Public Sector Performance Assessment: A Literature Analysis. Revista de Administração, Sociedade e Inovação (RASI), v. 7, n. 2, 59-79.

Prins, Ad AM et al. (2016). Using Google Scholar in research evaluation of humanities and social science programs: A comparison with Web of Science data. Research Evaluation, v. 25, n. 3, 264270.

Pilloni, M., Hamed, T. A., \& Joyce, S. (2020). Assessing the success and failure of biogas units in Israel: Social niches, practices, and transitions among Bedouin villages. Energy Research \& Social Science, 61, 101328.

Raven, R., Kern, F., Verhees, B., \& Smith, A. (2016). Niche construction and empowerment through socio-political work. A meta-analysis of six low-carbon technology cases. Environmental Innovation \& Societal Transitions, 18, 164-180.

Rip, A. \& Kemp, R. (1998) Technological change. In: Rayner, S., Malone, E.J. (Eds.), Human Choice and Climate Change, vol. 2. Resources and Technology. Battelle Press, Columbus, Ohio, 327-399.

Roberts, C., \& Geels, F. W. (2019). Conditions for politically accelerated transitions: Historical institutionalism, the multi-level perspective, and two historical case studies in transport and agriculture. Technological Forecasting \& Social Change, 140, 221-240.

Santos, J. B., \& D'Antone, S. (2014). Reinventing the wheel? A critical view of demand-chain management. Industrial Marketing Management, 43(6), 1012-1025. 
Smith, A. (2007). Translating sustainabilities between green niches and socio-technical regimes. Technology Analysis \& Strategic Management, 19(4), 427-450.

Smith, A., Stirling, A. \& Berkhout, F. (2005) The governance of sustainable socio-technical transitions. Research Policy, v 34, 1491-151.

Smith, A., Voß, J. P., \& Grin, J. (2010). Innovation studies and sustainability transitions: The allure of the multi-level perspective and its challenges. Research Policy, 39(4), 435-448.

Smith, A., \& Raven, R. (2012). What is protective space? Reconsidering niches in transitions to sustainability. Research Policy, 41(6), 1025-1036.

Smith, A., Stirling, Andy. (2018). Innovation, Sustainability and democracy. An analysis of grassroots contributions. Journal of Self-Governance \& Management Economics. 6 (1), 64.

Sorrell, S. (2015). Reducing energy demand: A review of issues, challenges, and approaches. Renewable \& Sustainable Energy Reviews, 47, 74-82.

Sorrell, S. (2018). Explaining sociotechnical transitions: A critical realist perspective. Research Policy, 47(7), 1267-1282.

Spinardi, G., \& Slayton, R. (2015). Greener Aviation Take-off (Delayed): Analysing Environmental Transitions with the Multi-Level Perspective. Science \& Technology Studies, v. 28, n. 1.

Strambach, S., \& Pflitsch, G. (2020). Transition topology: Capturing institutional dynamics in regional development paths to sustainability. Research Policy, 49(7), 104006.

Stirling, Andy. (2014). Transforming power. Social science and the politics of energy choices. Energy Research \& Social Science, 1, 83-95.

Tranfield, D., Denyer, D., \& Smart, P. (2003). Towards a methodology for developing evidence-informed management knowledge by means of systematic review. British Journal of Management, 14(3), 207-222.

Truffer, B., \& Coenen, L. (2012). Environmental innovation and sustainability transitions in regional studies. Regional Studies, 46(1), 1-21.

Turnheim, B., \& Geels, F. W. (2013). The destabilisation of existing regimes: Confronting a multidimensional framework with a case study of the British coal industry (1913-1967). Research Policy, 42(10), 1749-1767.

Turnheim, B., \& Nykvist, B. (2019). Opening up the feasibility of sustainability transitions pathways (STPs): Representations, potentials, and conditions. Research Policy, 48(3), 775-788.

Unruh, G. C. (2000). Understanding carbon lock-in. Energy Policy, 28(12), 817-830.

Unruh, G. C. (2002). Escaping carbon lock-in. Energy Policy, v. 30, n. 4, 317-325. 
Vähäkari N, Lauttamäki V, Tapio P, Ahvenainen M, Assmuth T, Lyytimäki J, Vehmas J. (2020). The future in sustainability transitions - Interlinkages between the multi-level perspective and futures studies, Futures.

Valencia, F.; Billi, M.; Urquiza, A. (2021). Overcoming energy poverty through micro-grids: an integrated framework for resilient, participatory sociotechnical transitions. Energy Research \& Social Science, v. 75, p. 102030, http://dx.doi.org/10.1016/j.erss.2021.102030.

Van de Ven, A.H. (1993). A community perspective on the emergence of innovations. Journal of Engineering \& Technology Management, v. 10: 23-51.

Verbong, G., \& Geels, F. (2007). The ongoing energy transition: lessons from a socio-technical, multi-level analysis of the Dutch electricity system (1960-2004). Energy Policy, 35(2), 1025-1037.

Zwartkruis, J. V., Berg, H., Hof, A. F., \& Kok, M. T. (2020). Agricultural nature conservation in the Netherlands: Three lenses on transition pathways. Technological Forecasting \& Social Change, $151,119235$.

Zheng, Chenglong; Kouwenberg, Roy. (2019). A Bibliometric Review of Global Research on Corporate Governance and Board Attributes. Sustainability, v. 11, n. 12, 1-25.

Wainstein, M. E., \& Bumpus, A. G. (2016). Business models as drivers of the low carbon power system transition: a multi-level perspective. Journal of Cleaner Production, 126, 572-585.

Wilkinson, S., Davidson, M., \& Morrison, G. M. (2020). Historical transitions of Western Australia's electricity system, 1880-2016. Environmental Innovation \& Societal Transitions, 34, 151-164. 